\title{
ANALISIS PERBEDAAN PENDAPATAN PETANI KARET DALAM MEMASARKAN BOKAR MELALUI KUB DAN NON KUB DI DESA JALUR PATAH KECAMATAN SENTAJO RAYA
}

\author{
Yuswandi, Meli Sasmi, Haris Susanto \\ Program Studi Agribisnis, Fakultas Pertanian \\ Universitas Islam Kuantan Singingi Teluk Kuantan \\ e-mail : melisasmi2011@gmail.com
}

\begin{abstract}
ABSTRAK
Penelitian ini bertujuan 1) Mengetahui perbedaan pendapatan petani karet KUB dan non KUB di Desa Jalur Patah, 2) Mengetahui tingkat efisiensi usaha petani KUB dan non KUB di Desa Jalur Patah, dan 3) Mengetahui permasalahan yang dihadapai petani dalam memasarkan bokar melalui KUB dan non KUB di Desa Jalur Patah. Pengambilan sampel dilakukan secara purposive. Responden yang diambil sebyak 60 orang terdiri dari petani KUB berjumlah 30 orang dan petani non KUB sebanyak 30 orang. Analis data menggunakan analisis matematik dan analisis statistik. Analisis matematikdilakukan untuk menganalisis tingkat keuntungan dan analisis efisiensi usaha (R/C). Sedangkan analisis statistik menggunakan Idependent Sample $T$ Test bertujuan untuk melihat ada tidak perbedaan pendapatan petani KUB dan non KUB, dan uji One-Way bertujuan untuk melihat kesamaan varian. Hasil Penelitian menunjukan bahwa secara matematik rata-rata pendapatan petani KUB dan non KUB berbeda yaitu pada petani KUB sebesar Rp. 1.940.375,- Sedangkan pada petani non KUB sebesara Rp. 592.803,33,- Secara statistik perbedaan pendapatan petani KUB dan non KUB berbeda sangat nyata pada taraf nyata 1 persen. Tingkat efisiensi usaha dalam memasarkan bokar petani KUB dengan nilai $R / C=20,00$, sedangkan pada petani non KUB dengan nilai $\mathrm{R} / \mathrm{C}=6,67$. Hal ini terlihat tingkat efisiensi usaha dan tingkat keuntungan petani dalam memasarkan bokar terdapat pada petani KUB. Permasalahan yang dihadapi petani dalam memasarkan bokar pada petani non KUB adalah rendahnya harga bokar ditingkat petani, rendahnya mutu, rendahnya produksi, rantai pemasaran yang cukup panjang.
\end{abstract}

Kata Kunci : Pendapatan, Pemasaran Bokar, KUB dan Non KUBs 


\section{PENDAHULUAN}

Sektor pertanian mempunyai peranan yang penting dalam meningkatkan pendapatan petani. Pendapatan petani secara umum dipengaruhi oleh beberapa komponen, yaitu jumlah produksi, harga jual, dan biaya-biaya yang dikeluarkan petani dalam pertaniannya. Hal ini perlu perhatian pemerintah terhadap sektor pertanian untuk memperbaiki taraf hidup masyarakat.

Propinsi Riau sebagai daerah yang memiliki potensi dalam pembangunan pertanian terutama sub sektor perkebunan. Disamping berperan dan mampu menggerakan sektor industri, juga mampu memberikan sumbangan yang besar terhadap devisa negara.

Kabupaten Kuantan Singingi merupakan salah satu Kabupaten di Provinsi Riau, terlihat gambaran ekonomi umumnya bertopang pada sektor pertanian terutama sub sector perkebunan. Terlihat dari total rencana tata ruang Wilayah Kabupaten Kuantan Singingi seluas $765.103 \mathrm{Km}^{2}$, Luas perkebunan yaitu seluas $244.300 \mathrm{Ha}(31,93$ persen), ini merupakan sektor basis bagi ekonomi daerah yang perlu ditingkatkan dan diperhatikan oleh pemerintah daerah.

Pembangunan sub-sektor perkebunan di Kabupaten Kuantan Singingi terlihat pada tahun 2014 areal perkebunan tercatat seluas 279.249,90 Нa. Perkebunan tersebut sebagian besar dikelola oleh rakyat seluas $219.346,85 \mathrm{Ha}$ (78,55 persen), Perkebunan Besar Swasta 59.303,5 Ha (21,24 persen), dan selebihnya perkebunan Daerah $600 \mathrm{Ha}$ (0,21 persen), dapat dilihat pada Gambar 1.

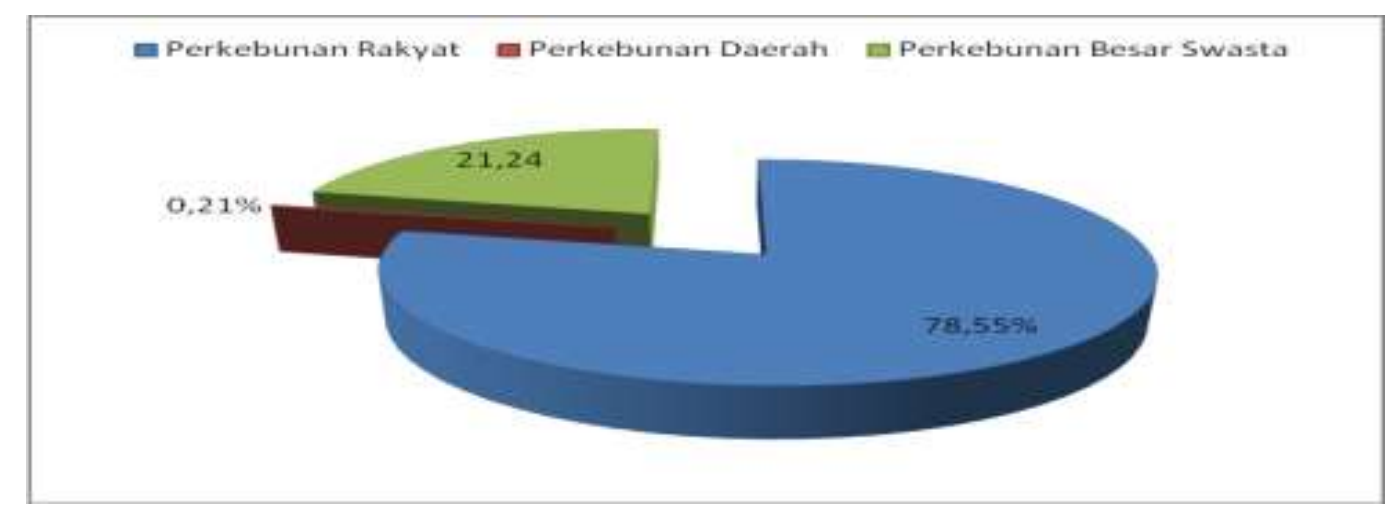

Gambar 1. Luas Perkebunan di Kabupaten Kuantan Singingi Tahun 2014

Sumber : Dinas Perkebunan Kabupaten Kuantan Singingi (2015)

Dari total areal perkebunan, karet merupakan lahan terluas yaitu seluas $145.389,95$ Ha (52,06 persen), kelapa sawit seluas $128.806,94$ Ha (46,13 persen), Kakao seluas 2.218,64 (0,79 persen) Ha dan aneka tanaman seluas 2.834,37 Ha (1,01 persen), hal ini dapat dilihat pada Gambar 2. 


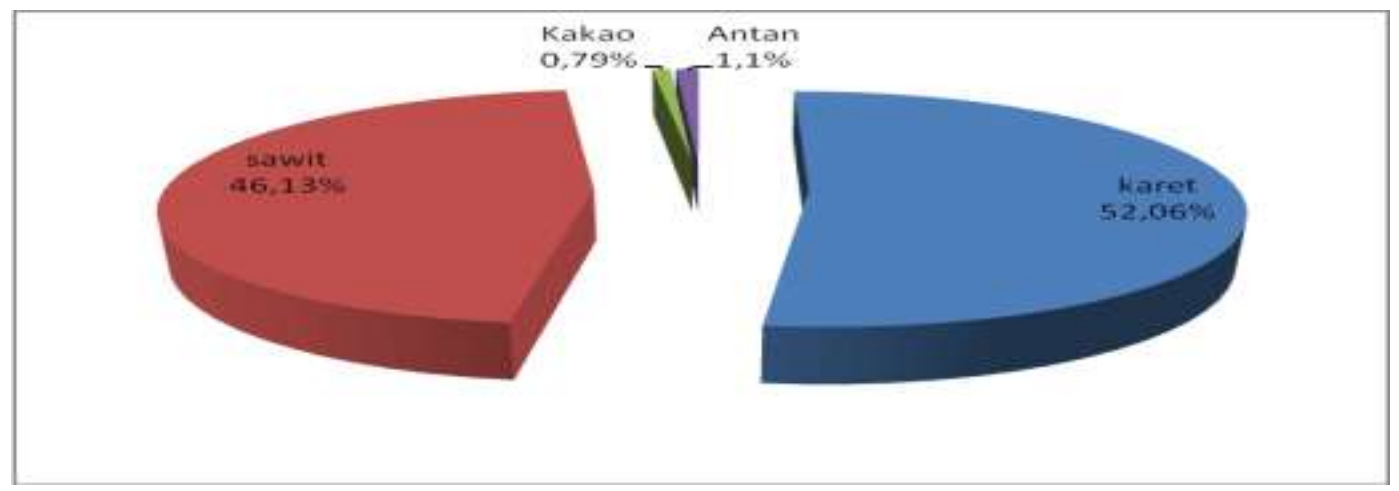

\section{Gambar 2. Luas Areal Perkebunan berdasarkan komoditi di Kabupaten} Kuantan Singingi Tahun 2014

Sumber : Dinas Perkebunan Kabupaten Kuantan Singingi (2014)

Perkebunan rakyat di Kabupaten Kuantan Singingi terutama komoditi karet kondisi pemasaran bahan olahan karet rakyat (bokar) umumnya masih kurang efisien. Hal ini terlihat masih banyak dijumpai rantai pemasaran bokar yang panjang dan bertingkat-tingkat. Belum adanya ketetapan harga dasar bokar oleh pemerintah, dan harga sangat bergantung pada fluktuasi harga karet dunia (Sasmi, 2013). Untuk peningkatan pendapatan petani perlu diimbangi dengan sistem pemasaran yang menguntungkan petani. Permasalahan yang sering dihadapi petani adalah permasalahan harga karet yang pada akhir-akhir ini sangat rendah sehingga menyebabkan pendapatan petani menjadi rendah.

Kelompok Usaha Bersama (KUB) merupakan suatu organisasi yang terdiri dari petani-petani yang memiliki kesamaan pandangan dan kebutuhan dapat digunakan sebagai wadah dalam mengembangkan dan melaksanakan kegiatan-kegiatan pemasaran. Kegiatan-kegiatan pembinaan KUB dapat memotivasi dan memfasilitasi untuk mengembangkan usahanya. Oleh karena itu, peranan KUB sangat dibutuhkan dalam rangka mengubah dan meningkatkan pendapatan petani.

Kabupaten Kuantan Singingi saat ini sudah memiliki beberapa kelompok tani pemasaran, salah satunya KUB Saiyo Sakato yang terletak di Desa Jalur Patah, Kecamatan Sentajo Raya. Berdirinya kelompok ini bertujuan untuk memutus mata rantai pemasaran sehingga harga karet ditingkat petani tetap tinggi, diharapkan dapat meningkatkan kesejahteraan petani di Desa Jalur Patah Teratak Air Hitam khususnya dan Kuantan Singingi umumnya.

Kesejahteraan petani karet umumnya masih tergolong rendah disebabkan belum optimalnya bagian harga yang diterima petani. Mutu bokar yang rendah serta panjangnya rantai pemasaran dalam menjual bokar, disebabkan posisi tawar petani yang lemah. Hal ini karena umumnya petani menjual bokar kepada pedagang pengumpul dengan harga yang relatif rendah. Petani sulit terlepas dari pedagang pengumpul disebabkan oleh keterikatan hutang, adanya hubungan keluarga dengan pedagang pengumpul serta beratnya beban atau tanggungan 
dalam keluarga. Rantai pemasaran yang panjang dapat menyebabkan adanya manipulasi pedagang untuk menekan harga. Kondisi saat sekarang petani karet di Desa Jalur Patah semakin memprihatinkan, harga karet yang semakin terpuruk ditambah lagi pedagang pengumpul dengan memainkan peran dalam penentuan harga.

KUB Saiyo Sakato berdiri pada tahun 2011 dan sampai saat ini anggotanya sudah mencapai 223 orang. Sistem pemasaran karet KUB Saiyo Sakato ini dengan sistem lelang, artinya kekuatan tawar atau harga ada di pihak kelompok, dengan demikian harga bokar kelompok terjual dengan harga yang diinginkan petani atau kelompok.

Rencana penelitian ini diawali dari kondisi harga karet dunia yang sangat rendah akan menyebabkan harga ditingkat petani jauh lebih rendah. Petani lebih banyak melakukan penjualan bokar melalui pedagang pengumpul di desa, dengan harga yang relatif rendah dibandingkan dengan harga di KUB. Adanya perbedaan harga bokar ditingkat pedagang pengumpul dengan kelompok namun masih banyak petani tidak tertarik untuk bergabung karena petani merasa diuntungkan jika menjual ke pedagang dengan beberapa pertimbangan, yaitu 1) mudah berhutang; 2) Petani menjual bokar dalam kondisi sangat basah yaitu banyak mengandung air, dijual dalam bentuk bokar basah padahal yang dihitung bokar kering.

Berdasarkan hal tersebut diatas maka perlu dilakukan kajian tentang apakah ada perbedaan pendapatan petani karet yang melakukan penjualan melalui kelompok dan non kelompok di Desa Jalur Patah dengan judul: "Analisis Perbedaan Pendapatan Petani Karet Dalam Memasarkan Bokar Melalui KUB dan Non KUB di Desa Jalur Patah Kecamatan Sentajo Raya. Tujuan penelitian ini adalah 1) Mengetahui perbedaan pendapatan petani karet KUB dan non KUB di Desa Jalur Patah, 2) Mengetahui tingkat efisiensi usaha petani KUB dan non KUB di Desa Jalur Patah, 3) Mengetahui permasalahan yang dihadapai petani dalam memasarkan bokar melalui KUB dan non KUB di Desa Jalur Patah, 4) Mengetahui karakteristik Petani KUB dan non KUB di Desa Jalur Patah.

\section{METODOLOGI}

\section{Tempat dan Waktu Penelitian}

Penelitian ini dilaksanakan di Desa Jalur Patah Kecamatan Sentajo Raya. Pertimbangan pemilihan lokasi dikarenakan salah satu desa memiliki Kelompok Usaha Bersama (KUB) di Kecamatan Sentajo Raya serta memiliki prestasi yang baik di Kabupaten Kuantan Singingi. Penelitian ini dilaksanakan selama empat bulan dimulai bulan Mei sampai Agustus 2015. 


\section{Penentuan Sampel}

Penelitian ini menggunakan metode survei, yaitu suatu cara penelitian untuk memperoleh fakta dan keterangan tentang sesuatu yang ingin diteliti. Penelitian ini dilakukan terhadap sampel, rumah tangga yang berusahatani karet baik yang tergabung dalam kelompok pemasaran bersama maupun yang tidak terlibat dalam kelompok (perorangan).

Pemilihan sampel petani Kelompok Usaha Bersama (KUB) dan non KUB dipilih secara purposive. Pemilihan pada KUB dipilih berdasarkan kriteria kelompok yang dinilai paling aktif di Kecamatan Sentajo raya. Sedangkan pemilihan sampel non KUB yang berdomisili di Desa Jalur Patah Kecamatan Sentajo Raya Kabupaten Kuantan Singingi dipilih secara puposive yang menjual pada beberapa pedagang pengumpul di Desa jalur Patah. Demi kebutuhan tersebut maka dipilih sebanyak 30 orang sampel dari kelompok dan 30 orang dari non kelompok. Secara rinci dapat dilihat pada Tabel 1.

Tabel 1. Populasi Petani KUB dan Non KUB di Desa Jalur Patah

\begin{tabular}{llcc}
\hline No & \multicolumn{1}{c}{ Uraian } & Populasi (org) & Sampel (Org) \\
\hline 1. & Kelompok Usaha Bersama Saiyo Sekato & 223 & 30 \\
2. & Petani Non Kelompok & 298 & 30 \\
\hline & Total & $\mathbf{5 2 1}$ & $\mathbf{6 0}$ \\
\hline
\end{tabular}

Sumber: Data Olahan Hasil Penelitian

\section{Jenis dan Sumber Data}

Data yang dikumpulkan pada penelitian ini meliputi data primer dan sekunder. Data primer diperoleh dengan dengan melakukan pengamatan langsung ke lokasi penelitian, serta wawancara langsung dengan responden menggunakan daftar pertanyaan (kuesioner) yang telah dipersiapkan. Data primer diperoleh langsung dari petani sampel meliputi :

1. Profil petani (umur, pendidikan, jenis kelamin,anggota keluarga).

2. Profil usaha seperti luas areal tanaman, produksi, harga, dan biaya serta data yang berhubungan dengan penelitian.

Data sekunder yaitu data yang diambil dari instansi terkait, seperti monografi daerah penelitian, luas areal perkebunan karet, produksi, data harga ditingkat petani, pedagang dan pabrik, dan lain-lain yang berkaitan dengan penelitian.

\section{Metode Analisis Data}

Metode analisis digunakan adalah metode deskriptif dan metode kuantitatif. Untuk menjawab tujuan dan hipotesis dilakukan analisis data dengan menghitung Analisis Keuntungan secara matematik dan Analisis Uji beda (T-test) secara statistik. 


\section{Analisis Keuntungan}

Analisis pendapatan bersih adalah hasil pengurangan antara total penerimaan dengan total biaya yang dikeluarkan. Untuk menganalisis pendapatan bersih petani karet secara umum dapat digunakan rumus menurut soekartawi (1987), yaitu :

$$
\begin{gathered}
\pi=T R-T C \\
T R=Y . P y
\end{gathered}
$$

Keterangan :

$\pi \quad=$ Pendapatan bersih

TR $=$ Total Penerimaan

TC = Total biaya

$\mathrm{Y} \quad=$ Produksi

Py = Harga Bokar

Untuk mengetahui efisisensi suatu usaha dapat digunakan rumus :

$$
R / C=\frac{T R}{T C}
$$

Soekartawi (2006), jika dihasilkan nilai $\mathrm{R} / \mathrm{C}=1$, maka kegiatan usaha dilakukan tidak mengalami keuntungan ataupun kerugian, atau dengan kata lain total penerimaan yang diperoleh sama besarnya dengan total biaya produksi yang dikeluarkan. Jika R/C > 1, maka penerimaan yang diperoleh lebih besar daritotal biaya produksi yang dikeluarkan sehingga kegiatan usaha mengalami keuntungan. Jika $\mathrm{R} / \mathrm{C}<1$, makatotal penerimaan yang diperoleh lebih kecil dari total biaya produksi yang dikeluarkan, sehingga kegiatan usaha yang dijalankan mengalami kerugian.

\section{Uji Dua Sampel Tidak Berpasangan/Independent Sample T Test}

Perhitungan menggunakan rumus (Priyatno, 2010) sebagai berikut :

$$
t=\frac{x 1-x 2}{\frac{\sqrt{(n 1-1) s 1^{2}+(n 2-1) s 2^{2}}}{n 1+n 2-2}\left[\frac{1}{n 1}+\frac{1}{n 2}\right]}
$$

\section{Keterangan :}

X1 = Kelompok Pemasaran Bokar (KUB) diasumsikan kelompok A $\mathrm{X} 2$ = Pemasaran non kelompok, diasumsikan kelompok B. 
Perbandingan yang dilakukan terhadap pemasaran bokar secara KUB dengan Non-KUB adalah dengan membandingkan nilai margin pemasaran. Semakin kecil nilai margin maka pemasaran semakin efisien.

Sebelum dilakukan uji $\mathrm{t}$ test (Independen Sample $\mathrm{T}$ test) terlebih dahulu dilakukan uji kesamaan varian (homogenitas) dengan F test (Levene's Test), artinya jika varian sama, maka uji t menggunakan Equal Variances Assumed (diasumsikan varian sama) dan jika varian berbeda menggunakan Equal Variances Not Assumed (diasumsikan varian berbeda). Adapun langkah-langkah Uji F sebagai berikut :

\section{Menentukan Hipotesis}

Ho: Kedua varian adalah sama (Varian kelompok kelas A dan kelas B adalah sama)

Ha: Kedua varian adalah berbeda (varian kelompok kelas A dan kelas B berbeda). 1.Kriteria Pengujian (berdasar signifikansi)

Ho diterima jika signifikansi $>0,05$

Ho ditolak jika signifikansi $<0,05$

Langkah-langkah Uji t

1. Menentukan Hipotesis

Ho : tidak ada perbedaan pendapatan antara petani KUB dengan petani Non-KUB Ha : Ada perbedaan pendapatan antara petani

\section{HASIL DAN PEMBAHASAN}

\section{Perkembangan Kelembagaan Pemasaran (KUB) Saiyo Sakato}

Melihat kondisi sebelum terbentuknya KUB, petani berada pada posisi tawar yang lemah, sulit mendapatkan informasi harga. Pada awalnya proses pembentukan KUB ini petani melakukan rapat dengan membentuk tim kecil yang dihadiri petugas atau penyuluh lapangan, kemudian terbentuk pengurus dan dikukuhkan oleh Dinas Perkebunan. Adapun tujuan didirikannya KUB Saiyo Sekato adalah sebagai berikut : 1) Meningkatkan pendapatan dan kesejahteraan anggota kelompok tani, 2) Meningkatkan mutu bokar anggota kelompoktani, 3) Meningkatkan akses pasar dan posisi tawar kelompok tani, 4) Tumbuhnya kelompok tani yang mampu berdayasaing.

\section{Produksi dan Mutu Bokar}

Usahatani karet yang dilakukan petani di Desa Jalur Patah pada dasarnya bersifat komersial, dimana produksi yang dihasilkan umumnya dijual dengan tujuan untuk mendapatkan imbalan yang dapat untuk memenuhi kebutuhan hidup petani dengan keluarganya. Rata-rata produksi karet petani KUB adalah 215,07 kg per minggu sedangkan produksi karet petani non KUB adalah $84,90 \mathrm{~kg}$ per minggu. Kualitas atau mutu bokar petani KUB lebih bagus dibandingkan mutu bokar petani non KUB karena petani KUB 
mempunyai aturan dalam pembuatan bokar sedangkan petani non KUB tidak mempunyai aturan.

\section{Analisis dan Pendapatan Petani dalam Memasarkan Boks}

Biaya rata-rata berat susut bokar petani KUB sebesar Rp. 475 per kg atau sebesar 5 persen dari harga berat bokar per kilogram. Sedangkan biaya berat susut bokar non KUB rata-rata sebesar Rp. 1.127,33 per kg, untuk lebih jelas dapat dilihat pada Tabel 2.

Tabel 2. Biaya Pemasaran Bokar pada petani KUB dan non KUB di Desa Jalur Patah

\begin{tabular}{clcrr}
\hline No. & $\begin{array}{c}\text { Kelompok Petani } \\
\text { Sampel }\end{array}$ & $\begin{array}{c}\text { Total Berat } \\
\text { Susut } \mathbf{( K g )}\end{array}$ & $\begin{array}{c}\text { Biaya Berat } \\
\text { Susut (Rp/kg) }\end{array}$ & $\begin{array}{c}\text { Total Biaya Berat } \\
\text { Susut (Rp) }\end{array}$ \\
\hline 1 & Petani KUB & 10,75 & 475 & 102.125 \\
2 & Petani Non KUB & 13,66 & $1.127,33$ & $95.278,50$ \\
\hline
\end{tabular}

Dilihat dari Tabel 8. biaya berat susut bokar yang terbesar terdapat pada petani non KUB yaitu sebesar Rp. 1.127,33 sedangkan pada penjualan melalui KUB hanya sebesar Rp. 475. Tingginya biaya berat susut dihitung berdasarkan beberapa hal diantaranya adalah petani menjual dalam bentuk berat basah. padahal yang dihitung adalah berat kering. Pada petani non KUB beranggapan semakin basah karet semakin berat bobotnya, padahal jika dilihat dari pemotongan berat tersebut mencapai Rp. $1.127,33$ per $\mathrm{kg}$ atau rata-rata pemotongan 16,17 persen dari berat per kilogram. Kemudian berdasarkan mutu, kebiasan petani non KUB selalu memasukkan benda-benda asing untuk menambah berat, padahal jika bokar kotor maka pemotongan yang dilakukan pedagang semakin besar karna pabrik akan melakukan klasifikasi mutu bokar dengan menetapkan kelas-kelas mutu dan penetapan Kadar Karet Kering (KKK).

Rendahnya biaya berat susut pada petani KUB disebabkan karen kelompok telah menetapkan standar mutu kepada masing-masing anggota. Apabila anggota melanggar aturan maka diberikan sangsi untuk beberapa kali pelelangan tidak boleh ikut bahkan ada yang dikeluarkan. Penetapan standar mutu oleh kelompok seperti meingkatkan kadar kering dengan tidak merendam, tidak mencampurkan dengan bahan-bahan lain.

Dengan bergabungnya petani memasarkan bokar melalui KUB maka daya tawar petani menjadi kuat karena dengan mutu bokar yang tinggi dan jumlah volume yang cukup besar maka petani akan bisa melakukan negosiasi harga dengan melakukan pemasaran dengan sistem lelang. Pemasaran sistem lelang pada KUB ini di lakukan dengan mencari informasi harga tertinggi pada beberapa pedagang atau pabrik baik yang berada di daerah mapun di luar daerah. Penawaran harga yang paling tertinggi dalam proses lelang itulah yang akan menjadi pemenag lelang. Pada proses penjualan ini yang menanggung proses biaya pelelangan dan biaya transportasi untuk mengangkut ke pabrik adalah 
pemenag lelang sehingga petani KUB dalam memasarkan bokarnya lebih efisien. Sesuai dengan hasil penelitian Sasmi (2013), tentang analisis pemasaran bahan olahan karet rakyat di Kabupaten Kuantan Singingi yang menghitung efisiensi saluran pemasaran pada enam saluran pemasaran yang terdiri dari tiga saluran melalui kelompok dan tiga dari saluran non kelompok maka yang lebih efisien adalah saluran pada kelompok yaitu yang menjual pada kelompok pemasaran bersama dengan sistem lelang.

Penerimaan merupakan hasil yang diterima petani dalam bentuk rupiah yang diperoleh dari penjualan bokar dengan harga jual bokar baik melalui KUB dan non KUB. Penerimaan dipengarui oleh volume dan harga, besar kecilnya volume akan berkaitan langsung dengan luas lahan produksi petani, semakin luas lahan produksi maka semakin tinggi volume yang didapatkan serta harga yang cukup tinggi penerimaan yang diterima petani akan semakin besar.

Himawati (2006) menyatakan bahwa penerimaan merupakan hasil kali antara harga dengan total produksi dengan rumus sebagai berikut. TR=Py $x$ y, dimana TR adalah total revenue, Py adalah harga dan $\mathrm{Y}$ adalah total produksi. Besarnya penerimaan yang diperoleh oleh petani KUB dan Non KUB lebih rinci dijelaskan pada Tabel 3.

Tabel 3. Penerimaan Petani KUB dan Non KUB di Desa Jalur Patah Per Minggu

\begin{tabular}{ccccr}
\hline No. & \multicolumn{1}{c}{ Uraian } & Volume (Kg) & Harga (Rp) & Penerimaan $\mathbf{( R p )}$ \\
\hline 1 & Petani KUB & 215 & 9.500 & 2.042 .500 \\
2 & Petani Non KUB & 85,17 & $6.986,67$ & $592.803,33$ \\
\hline
\end{tabular}

Sumber : Data Olahan Hasil Penelitian

Tabel 3. Menunjukkan bahwa penerimaan petani KUB dan non KUB terdapat perbedaan, besarnya penerimaan yang diterima petani KUB adalah sebesar Rp. 2.042,500,- sedangkan penerimaan yang diterima petani non KUB adalah Rp. 595,103.500, selisih penerimaan petani KUB dan non KUB adalah sebesar Rp. 1.447,396,67. Terjadinya perbedaan penerimaan petani KUB dan non KUB disebabkan oleh volume yang dihasilkan petani KUB jauh lebih besar dibandingkan petani non KUB, semakin besar volume bokar yang dihasilkan maka semakin tinggi penerimaan yang diterima oleh petani. Harga bokar petani KUB juga lebih tinggi dibandingkan harga bokar ditingkat petani non KUB, semakin tinggi harga bokar tentu akan berdampak terhadap penerimaan petani. Tingginya harga ditingkat petani KUB disebabkan karena tingginya mutu bokar (KKK), bokar tidak mengandung sampah atau tatal. Untuk mengetahui perbedaan penerimaan petani KUB dan non KUB.

Pendapatan atau keuntungan merupakan tujuan setiap jenis usaha yang dilakukan. Keuntungan dapat dicapai jika jumlah penerimaan yang diperoleh dari hasil penjualannya lebih besar dan juga ditentukan oleh besarnya biaya, semakin rendah biaya pemasaran dan semakin besar penerimaan maka maka keuntungan 
semakin tinggi. Untuk mengetahui pendapatan bersih petani KUB dan Non KUB, dapat dilihat pada Tabel 4 .

Tabel 4. Pendapatan Bersih Petani KUB dan Non KUB di Desa Jalur Patah

\begin{tabular}{|c|c|c|c|c|c|c|c|}
\hline No. & Uraian & $\begin{array}{c}\text { Volume } \\
\text { (kg/minggu) }\end{array}$ & $\begin{array}{l}\text { Harga } \\
\text { (Rp) }\end{array}$ & $\begin{array}{l}\text { Penerimaan } \\
\text { (Rp) }\end{array}$ & $\begin{array}{c}\text { Biaya } \\
(\mathrm{Rp} / \mathrm{kg})\end{array}$ & $\begin{array}{c}\text { Total } \\
\text { Biaya } \\
\text { (Rp) }\end{array}$ & $\begin{array}{c}\text { Pendapatan } \\
\text { (Rp) }\end{array}$ \\
\hline 1 & 2 & 3 & 4 & $5(3 \times 4)$ & 6 & 7 & $8(5-7)$ \\
\hline 1 & $\begin{array}{l}\text { Petani } \\
\text { KUB }\end{array}$ & 215 & 9.500 & 2.042 .500 & 475 & 102.125 & $1.940,375$ \\
\hline 2 & $\begin{array}{l}\text { Petani } \\
\text { Non KUB }\end{array}$ & 85,17 & $6.986,67$ & $595.103,33$ & $1.127,33$ & $95.278,50$ & 506,052 \\
\hline
\end{tabular}

Sumber : Data Olahan Hasil Penelitian

Dari Tabel 4. terlihat perbedaan pendapatan antara petani KUB dan non KUB hal ini dipengaruhi oleh besarnya jumlah produksi, biaya dan harga jual. Tingginya pendapatan yang diperoleh petani KUB disebabkan rata-rata produksi petani KUB lebih tinggi dibanding non KUB, harga jual lebih tinggi dari non KUB, biaya berat susut lebih rendah dibandingkan non KUB, sehingga total pendapatan lebih tinggi dibandingkan non KUB tersebut.

Penyebab utama rendahnya pendapatan petani non KUB selai jumlah produksi dan harga yang lebih rendah hal ini juga disebabkan karena rendahnya mutu bokar petani non KUB sehingga akan berimbas pada biaya berat susut bokar. Kadar karet kering (KKK) non KUB lebih rendah serta panjang rantai pemasaran pada non KUB. Untuk mengatasi hal ini guna untuk memperoleh pendapatan yang cukup tinggi disarankan petani hendaknya berinisiatif untuk bergabung dalam memasarkan bokar melalui KUB.

\section{Analisis Efisiensi Usaha Petani dalam Memasarkan Bokar}

Efisiensi usaha dalam memasarkan bokar oleh petani adalah perbandingan antara total penerimaan terhadap total biaya yang dikeluarkan selama satu kali proses produksi. Semakin besar dari 1 maka nilai R/C maka semakin efisien atau semakin menguntungkan. Besarnya nilai R/C untuk lebih jelas dapat dilihat pada Tabel 5.

Tabel 5. Tingkat Efisiensi Usaha Pemasaran Bokar Melalui KUB dan Non KUB di Desa Jalur Patah

\begin{tabular}{ccccc}
\hline No. & Uraian & Penerimaan (TR) & Biaya (TC) & $\begin{array}{c}\text { Efisiensi Usaha } \\
\text { (TR/TC) }\end{array}$ \\
\hline 1 & 2 & 3 & 4 & 5 \\
\hline 1 & Petani KUB & 2.042 .500 & 102.125 & 20 \\
2 & Petani Non KUB & $595.103,33$ & $95.278,50$ & 6,66 \\
\hline
\end{tabular}

Sumber : Data Olahan 
Tabel 5. menunjukan bahwa petani karet KUB memperoleh efisiensi sebesar 20 Artinya setiap satu rupiah biaya pemasaran yang dikeluarkan akan memperoleh pendapatan kotor sebesar Rp. 20 atau akan memperoleh keuntungan sebesar Rp. 19. Sedangkan pada petani non KUB memperoleh efisiensi sebesar Rp. 6,66 Artinya Setiap satu rupiah biaya pemasaran yang dikeluarkan akan memperoleh pendapatan kotor sebesar Rp. 6,66 atau tingkat keuntungan sebesar Rp. 5,66. Dengan demikian tingkat efisiensi yang dicapai petani KUB lebih besar dibanding petani non KUB.

Tingginya tingkat efisiensi petani KUB dibanding petani non KUB sebesar hal ini dipengaruhi jumlah volume lebih besar, harga tinggi dibandingkan non KUB, biaya pemasaran lebih rendah dibanding petani non KUB. Jika penerimaan jauh lebih tinggi dibanding total pengeluaran maka keuntungan yang diterima petani menjadi lebih tinggi. Tingkat keuntungan pada hasil analisis ini sangat besar karena perhitungan biaya hanya dihitung berdasarkan biaya pemasaran saja sedangkan biaya dalam usahatani tidak dilakukan perhitungan.

\section{Analisis Statistik}

Sebelum dilakukan uji Independent Samples $T$ Test harus dilakukan terlebih dahulu uji kesamaan varian (homogenitas) dengan F test (Levene's Test), uji ini digunakan untuk mengetahui apakah varian ke dua kelompok sama. Jika varian sama, maka uji t menggunakan Equal Variances Assumed (diasumsikan varian sama) dan jika varian berbeda menggunakan Equal variances Not Assumed (diasumsikan varian berbeda). Data yang memenuhi syarat adalah jika varian sama atau subjek berasal dari kelompok yang homogen (Priyatno, 2010).

\section{Uji Homogenitas dan Uji Beda Rata-rata Sampel Independen (Uji T-test)}

Hasil uji kesamaan varian (homogenitas) dengan meggunakan uji $F$ test (Levene,s Test). Nilai signifikansi pada uji $\mathrm{F}$ adalah 0.00 berbeda nyata pada taraf nyata 1 persen. maka dapat disimpulkan bahwa kedua varian atau pendapatan petani KUB dan non KUB dalam menjual bokar adalah berbeda. Dengan demikian dapat dilanjutkan dengan Uji Beda Dua Sampel /Independen (T Test). Hasil analisis dapat dilihat pada Tabel 6 .

Tabel 6. Analisis Uji Beda Pendapat Petani yang Memasarkan Bokar Melalui KUB dengan Non KUB di Desa Jalur Patah

\begin{tabular}{|c|c|c|c|c|c|c|}
\hline \multirow[t]{2}{*}{ Kelompok } & \multirow[t]{2}{*}{$\mathbf{N}$} & \multicolumn{3}{|c|}{$\begin{array}{c}\text { Levene's Test for Equality of } \\
\text { Variances }\end{array}$} & \multirow{2}{*}{$\begin{array}{l}\text { T-test } \\
\text { T-test }\end{array}$} & \multirow{2}{*}{$\begin{array}{c}\text { Sig } \\
\text { Sig }\end{array}$} \\
\hline & & Mean & $F$ & Sig & & \\
\hline $\begin{array}{l}\text { Pendapatan Equal Variances } \\
\text { Assumed }\end{array}$ & 30 & 1940375.00 & 26.254 & .000 & 10.174 & .000 \\
\hline $\begin{array}{l}\text { Kelompok Equal Variances } \\
\text { not Assumed }\end{array}$ & 30 & 592803.33 & & & 10.174 & .000 \\
\hline
\end{tabular}

Sumber : Data Olahan Hasil Penelitian 
Hasil analis seperti pada Tabel 6. Menunjukkan bahwa pada uji F nilai F hitung lebih besar dari $\mathrm{F}$ tabel, maka dapat disimpulkan bahwa kedua varian (pendapatan petani KUB dan Non KUB) sangat berbeda nyata. Selanjutnya dilihat dari uji T-test seperti pada Tabel 10. Dapat dilihat nilai $t$ hitung (Equal variances assumed ) adalah 10.174 lebih besar dari $t$ tabel maka pendapatan petani dalam memasarkan bokar melalui KUB dan non KUB berbeda sangat nyata. Pada tabel terlihat rata-rata (mean) pendapatan rata-rata petani KUB lebih besar dibandingkan petani non KUB. Rata-rata mean diference sebesar 1.347.571,66 (1.940.375.00-592803.33) dan perbedaan berkisar antara 1082442.191 sampai 1612701.142.

\section{Kesimpulan}

\section{KESIMPULAN DAN SARAN}

Dari hasil penelitian ini dapat disimpulkan bahwa pemasaran bokar oleh petani KUB dan non KUB dapat disimpulkan bahwa :

1. Rata-rata pendapatan petani KUB dan non KUB berbeda yaitu pada petani KUB sebesar Rp. 1.940.375, Sedangkan pada petani non KUB sebesar Rp. $592.803,33$.

2. Secara statistik perbedaan pendapatan petani KUB dan non KUB berbeda sangat nyata pada taraf nyata 1 persen.

3. Tingkat efisiensi usaha dalam memasarkan bokar petani KUB dengan nilai $\mathrm{R} / \mathrm{C}=20,00$, sedangkan pada petani non KUB dengan nilai $\mathrm{R} / \mathrm{C}=6,67$.

4. Permasalahan yang dihadapai petani dalam memasarkan bokar pada petani non KUB adalah rendahnya harga bokar ditingkat petani, rendahnya mutu, rendahnya produksi, rantai pemasaran yang cukup panjang sehingga pemasaran bokar kurang efisien.

\section{Saran}

1. Agar meningkatnya pendapatan petani karet maka disarankan hendaknya membentuk kelompok pemasaran karet secara bersama di setiap desa.

2. Daya tawar petani akan lebih baik apabila petani berada pada suatu lembaga sehingga harga akan lebih tinggi.

3. Akan mudah terwujudnya program pemerintah tentang bokar bersih karena mutu bokar pada KUB lebih diperhatikan

\section{DAFTAR PUSTAKA}

Dinas Perkebunan. 2015. Buku Database Perkebunan tahun 2014 Teluk Kuantan Himawati. 2006. Analisa Resiko Pinansial Usaha Peternakan Pedaging pada Peternakan Plasma Kemitraan KUD "Sari Murni" Di Kecamatan 
Bululawang Kabupaten Malang Fakultas Peternakan Universitas Brawijaya, Malang.

Prayitno. 2010. Pemahaman Analisa Statistika dengan SPSS. Penerbit Medikon. Yogyakarta.

Sasmi M. 2013. Analisis Pemasaran Bahan Olah Karet Rakyat di Kabupaten Kuantan Singing. [tesis]. Pekanbaru (ID) : Program Pasca Sarjana Fakultas Pertanian Universitas Riau.

Soekartawi. 1993. Prinsip Dasar Manajemen Pemasaran Hasil-Hasil Pertanian. PT. Raja Grafindo. Jakarta.

Soekartawi. 2006. Analisis Usahatani. Penerbit Universitas Indonesia. Jakarta. 